7. Reprod. Fert. (1972) 30, 321-323

\title{
INHIBITION OF PARTURITION IN SWINE BY THE DITHIOCARBAMOYLHYDRAZINE, ICI 33828*
}

\author{
N. L. FIRST \\ Department of Meat and Animal Science, \\ University of Wisconsin, Madison 53707, U.S.A.
}

(Received 7th February 1972, accepted 13th March 1972)

Two experiments were conducted to determine if methallibure (ICI 33828), a hypothalamus-inhibiting dithiocarbamoylhydrazine (Malven, 1971) would prevent parturition.

In Exp. 1, thirteen pregnant Yorkshire, Poland China and Yorkshire $\times$ Poland China gilts were divided into three groups. Three gilts were assigned to be controls, four were fed $150 \mathrm{mg}$ ICI $33828 /$ gilt/day from the 100 th to the 116 th day of gestation and the six remaining gilts received ICI 33828 from the 100th day of gestation until parturition. Piglet numbers and weights were determined on the day of parturition.

In Exp. 2, fourteen pregnant Yorkshire or Poland China sows were randomly assigned to be untreated controls or fed $200 \mathrm{mg}$ ICI 33828/sow/day from Day 100 of gestation until parturition. Piglet numbers and weights were obtained at birth and at 1 week of age. The females in both experiments were checked daily for evidence of milk ejection.

The duration of gestation was significantly longer $(P<0.05)$ for sows and gilts treated with ICI 33828 (Tables 1 and 2). The gilts removed from treatment at Day 116 did not litter until Day 118, indicating that the physiological changes initiating parturition in ICI 33828-treated sows must have started on or before Day 116.

Milk ejection first occurred on the day of, or the half day preceding, parturition in all groups. It was significantly later in gestation for sows and gilts treated with ICI $33828(P<0.05)$. This differs from the data of Nellor (1963) where treatment of sows with 6-methyl-17-acetoxy-progesterone prevented parturition but milk ejection occurred on the date that parturition was normally due. This difference is probably due to different sites of action of the two drugs, ICI 33828 being a hypothalamic inhibitor and known to block oxytocin release (Garbers \& First, 1968).

Fewer sows exhibited post-partum oestrus after treatment with ICI 33828 (Table 2), though the day on which post-partum oestrus occurred was not significantly different from that for controls.

The number of live or dead pigs at birth and the mean birth weights did not differ significantly between treatment groups in either experiment. In Exp. 2, litters from sows treated with ICI 33828 were heavier at birth but the mortality

\footnotetext{
* Paper No. 603 from the Department of Meat and Animal Science.
} 
from birth to 1 week of age was greater than that of the controls $(P<0.01)$. There was no significant difference in piglet or litter weights at 1 week of age.

The mechanism through which ICI 33828 prolonged gestation is not known. The corticosteroid, dexamethasone, when administered to swine fetuses or to the mother will induce parturition (North, 1971), as it does in sheep (Liggins, 1968). The fetal pituitary and its release of ACTH may also be necessary for the initiation of parturition in swine, as in sheep (Liggins, Kennedy \& Holm, 1967; Liggins, 1968). If it is assumed that the teratological changes reported to occur in the fetuses when the sow is treated with ICI 33828 (King, 1969; Christenson, Schafer, Teague \& Grifo, 1971) are evidence that the drug crosses the placenta,

\section{TABLE 1}

DATA IN EXP. 1 FOR MEAN GESTATION LENGTH, FIRST DAY OF MILK EJECTION, AND LITTER SIZE OF CONTROL AND ICI 33828-TREATED GILTS AND MEAN WEIGHT OF PIGLETS AT BIRTH

\begin{tabular}{|c|c|c|c|c|c|c|c|c|c|}
\hline \multirow{3}{*}{ Treatment } & \multirow{3}{*}{$\begin{array}{l}\text { No. } \\
\text { of } \\
\text { gills }\end{array}$} & \multirow{2}{*}{\multicolumn{2}{|c|}{$\begin{array}{l}\text { Milk ejection, } \\
\text { 1st day }\end{array}$}} & \multirow{2}{*}{\multicolumn{2}{|c|}{ Gestation }} & \multicolumn{4}{|c|}{ Piglets } \\
\hline & & & & & & \multicolumn{2}{|c|}{ No. borm } & \multicolumn{2}{|c|}{ Average wt $(l b)$} \\
\hline & & Days & S.D. & Days & S.D. & Live & Dead & Live & Dead \\
\hline Control & 3 & $114 \cdot 7 *$ & 0.58 & $115^{*}$ & 0.0 & 8 & 1 & 3.0 & 1.5 \\
\hline $\begin{array}{l}\text { ICI } 33828 \\
100 \text { to } 116 \text { days }\end{array}$ & 4 & $118 \cdot 0$ & $1 \cdot 83$ & $118 \cdot 3$ & $1 \cdot 71$ & $5 \cdot 8$ & $1 \cdot 3$ & $3 \cdot 7$ & $1 \cdot 8$ \\
\hline $\begin{array}{l}\text { IGI } 33828 \\
100 \text { days to parturition }\end{array}$ & 6 & $118 \cdot 7$ & 0.82 & $118 \cdot 7$ & 0.82 & $7 \cdot 8$ & 1.8 & $3 \cdot 2$ & 1.9 \\
\hline
\end{tabular}

* Significantly less than the other two means, $P<0.05$.

TABLE 2

DATA IN EXP. 2 FOR MEAN GESTATION LENGTH, FIRST DAY OF MILK EJECTION, DAY OF post-partum OESTRUS AND LITTER SIZE OF CONTROL AND IGI 33828-TREATED SOWS AND MEAN WEIGHTS OF LITTERS AT BIRTH AND AT 1 WEEK OF AGE

\begin{tabular}{|c|c|c|c|c|c|c|c|c|c|c|c|c|}
\hline \multirow[t]{2}{*}{ Treatment } & \multirow{2}{*}{$\begin{array}{l}\text { No. } \\
\text { of } \\
\text { sows }\end{array}$} & \multicolumn{2}{|c|}{$\begin{array}{l}\text { Milk ejection, } \\
\quad \text { lst day }\end{array}$} & \multicolumn{2}{|c|}{$\begin{array}{c}\text { Gestation } \\
\text { length }\end{array}$} & \multicolumn{2}{|c|}{$\begin{array}{c}\text { Post-partum } \\
\text { oestrus }\end{array}$} & \multicolumn{2}{|c|}{$\begin{array}{c}\text { No. of } \\
\text { piglets born }\end{array}$} & \multirow{2}{*}{$\begin{array}{c}\text { No. } \\
\text { dead } \\
\text { birth to } \\
1 \text { week }\end{array}$} & \multicolumn{2}{|c|}{$\begin{array}{l}\text { Litter wt } \\
\quad(l b)\end{array}$} \\
\hline & & Day & $S . D$. & Days & S.D. & No. & Day & Live & Dead & & Birth & 1 week \\
\hline Control & 7 & $114 \cdot 1$ & $2 \cdot 0$ & $114 \cdot 1$ & $2 \cdot 0$ & $6^{*}$ & 3.8 & $6 \cdot 7$ & 0.15 & 0 & 20.5 & $37 \cdot 0$ \\
\hline ICI 33828 & 7 & $118^{*}$ & $2 \cdot 4$ & $118^{*}$ & $2 \cdot 4$ & 3 & $6 \cdot 3$ & $9 \cdot 3$ & 0.41 & $2 \cdot 7 * *$ & $29 \cdot 3^{*}$ & 33.7 \\
\hline
\end{tabular}

${ }^{*} P<0.05 . \quad{ }^{* *} P<0.01$.

then it is reasonable to expect that parturition was delayed due to inhibition of the release of fetal ACTH. How the parturition initiation mechanisms eventually overcome this inhibition is without explanation.

This research was supported by the College of Agricultural and Life Sciences, University of Wisconsin, Madison. The ICI 33828 was a gift from the Ayerst Laboratories, Rouses Point, New York. 


\section{REFERENCES}

Christenson, R. K., Schafer, J. H., Teague, H. S. \& Grifo, A. P., JR (1971) Influence of methallibure on early pregnancy in swine. 7. Anim. Sci. 33, 1156.

Gareers, D. L. \& First, N. L. (1968) The effects of ICI 33828 and oxytocin on milk ejection and milk production in the lactating sow. 7. Reprod. Fert. 17, 551.

KING, G. J. (1969) Deformities in piglets following administration of methallibure during specific stages of gestation. 7. Reprod. Fert. 20, 551.

LigGins, G. C. (1968) Premature parturition after infusion of corticotrophin or cortisol into fetal lambs. 7. Endocr. 42, 323.

Liggins, G. C., KeNNEDy, P. C. \& Holm, L. W. (1967) Failure of initiation of parturition after electrocoagulation of the pituitary of the fetal lamb. Am. F. Obstet. Gynec. 98, 1080.

Malven, P. C. (1971) Hypothalamic sites of action for methallibure (ICI 33828) inhibition of gonadotropin secretion. J. Anim. Sci. 32, 912.

Nellor, J. E. (1963) Induced delayed parturition in swine and cattle. Physiologist, 6, 244.

North, S. A. (1971) The induction of parturition with corticosteroid. M.S. thesis, University of Wisconsin, Madison. 